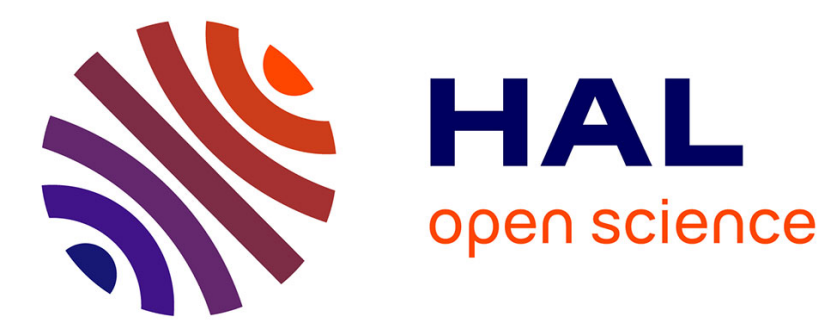

\title{
High pressure cell for use on four-circle diffractometers
}

H. Ahsbahs

\section{To cite this version:}

H. Ahsbahs. High pressure cell for use on four-circle diffractometers. Revue de Physique Appliquée, 1984, 19 (9), pp.819-821. 10.1051/rphysap:01984001909081900 . jpa-00245269

\section{HAL Id: jpa-00245269 https://hal.science/jpa-00245269}

Submitted on 1 Jan 1984

HAL is a multi-disciplinary open access archive for the deposit and dissemination of scientific research documents, whether they are published or not. The documents may come from teaching and research institutions in France or abroad, or from public or private research centers.
L'archive ouverte pluridisciplinaire HAL, est destinée au dépôt et à la diffusion de documents scientifiques de niveau recherche, publiés ou non, émanant des établissements d'enseignement et de recherche français ou étrangers, des laboratoires publics ou privés. 


\title{
High pressure cell for use on four-circle diffractometers
}

\author{
H. Ahsbahs \\ Mineralogisches Institut Marburg, F.R.G.
}

\begin{abstract}
Résumé. - Nous avons développé des cellules hautes pressions à " enclumes opposées » particulièrement adaptées à la géométrie des diffractomètres quatre-cercles rayons $\mathrm{X}$ et neutrons pour monocristaux. Elles ont pour particularité d'utiliser un joint transparent au rayonnement incident et de ce fait très peu de réflexions sont masquées par les éléments de la cellule. Le grand volume de l'échantillon ( $2 \mathrm{~mm}$ diamètre $\times 2 \mathrm{~mm}$ hauteur) nécessaire pour les expériences de diffraction des neutrons a limité jusqu'à présent à $20 \mathrm{kbar}$ la pression accessible avec cette cellule. Dans le cas des rayons $\mathrm{X}$, malgré le faible volume du cristal et l'utilisation d'enclumes de diamant la pression maximale est de $35 \mathrm{kbar}$ du fait du choix limité de matériau pour le joint : en pratique seul le béryllium peut être utilisé.
\end{abstract}

\begin{abstract}
High pressure cells with " opposed anvils ", especially suited for the conditions on four-circle diffractometers in X-ray and neutron single crystal experiments have been developed. An important feature of these devices is the application of gaskets permeable to the radiation used. By this the pressure cell can well be adapted to the diffracting geometry on four-circle diffractometers so that particularly few reflections are shadowed by parts of the cell. The large probe volume $(2 \mathrm{~mm}$ diameter $\times 2 \mathrm{~mm}$ height) necessary for neutron experiments has restricted the pressure achieved with this cell to $20 \mathrm{kbar}$ so far. Despite small volumes and diamond anvils the cell for the X-ray case is limited to $35 \mathrm{kbar}$ by the possible choice of the gasket material : practically, only beryllium can be used for this purpose.
\end{abstract}

High pressure cells with opposite anvils for single crystal X-ray diffraction experiments have been reported since 1965 [1-6]. Their common feature is that the crystal is situated in a steel gasket and hit by the $\mathrm{X}$-ray beam through the diamond anvils. By this technique it is possible to build very simple cells [4] or to reach pressures well exceeding 100 kbars [5]. Disadvantage is the restriction in the diffraction area accessible and difficulties with regards to shadowing effects of the gasket. The pressure cells described here avoid this points by application of permeable gaskets. However, the X-ray cell is not easy to operate and has a narrow pressure range compared to the pressure cells mentioned above, both caused by the use of beryllium gaskets.

Figures 1 and 2 show the pressure cells for X-ray and neutron experiments respectively. The important feature is the belt shaped diffracting window of width $\beta$, resulting in an accessible diffracting area depending on the diffractometer setting angle $\chi$ (Fig. 3) : for example with the "neutron cell" $\left(\beta=45^{\circ}\right)$ all reflections up to $2 \theta=90^{\circ}$ can be measured in the usual bisecting angle setting. For diffractometer setting angles $\chi$ less than $30^{\circ}$ there are no restrictions in $2 \theta$ and, for instance, for reflections with $\%=45^{\circ}$. diffracting angles 20 up to $\sim 130^{\circ}$ are allowed. The diffracting geometry and the pressure cell for X-ray experiments are described in detail elsewhere [7]. Here particularly the neutron cell shall be shown.

The crystal is situated between the anvils A in a hole in the gasket $G$ filled with a liquid not freezing at the pressure desired and with low absorption to neutrons. (Deuterated alcohols work quite well.) The hole in the gasket has an initial diameter of $2 \mathrm{~mm}$ and is $2 \mathrm{~mm}$ high. The crystal has to be a little bit smaller.

Force on the piston $\mathrm{P}$, well guided in the steel bushing $B$, is applied by a hydraulic ram with a piston fitting in the nut $\mathbf{M}$, compressing the buffer springs S via the distortion protector $\mathrm{D}$. The applied force is locked by fastening the nut $M$. The gasket $G$ and the anvils A must be strong enough to hold the pressure, they should have low absorption to neutrons, low incoherent scattering and above all low coherent scattering. The latter leads to a background depending 


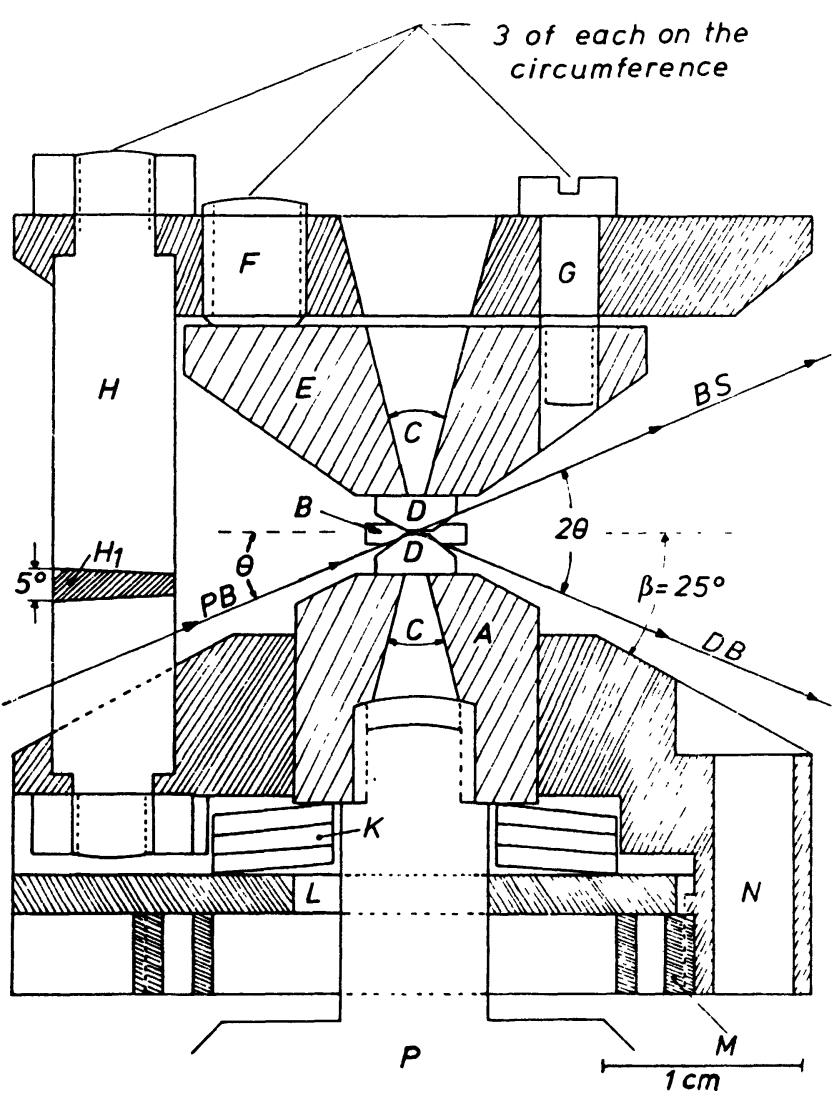

Fig. 1. - Cutaway cross-sectional drawing of the high pressure cell for $\mathrm{X}$-ray experiments. $\mathrm{PB}$, primary X-ray beam; DB, diffracted beam ; BS, to beam stop; A, movable diamond seat (piston); B, beryllium gasket; $\mathrm{D}$, diamond; $\mathrm{E}$, adjustable diamond seat; $\mathrm{H}$, connecting pillars, between upper and lower part of the pressure cell; $\mathrm{Hl}$, cross section of the pillars $\mathrm{H} ; \mathrm{K}$, buffersprings; L, distortion protector; $\mathrm{M}$, locking nut.

on $2 \theta$. Measuring a reflection in $(1)-20$ scan, necessary in neutron diffraction, the background could be quite different at different parts of the reflection scan. This is the reason we use a titanium-zirconium alloy for the gasket with no coherent scattering [8] and single crystal sapphire anvils. The few reflections of the probe crystal coinciding with sapphire reflections can be sorted out easily. Unfortunately the sapphire anvils fail above 10 kbars. For lack of stronger single crystals we used sintered tungsten carbide anvils for a structure determination at $20 \mathrm{kbar}[9,10]$. The errors in the vibration tensors (their asymmetry is of particular interest in this structure) raised by a factor of three compared with

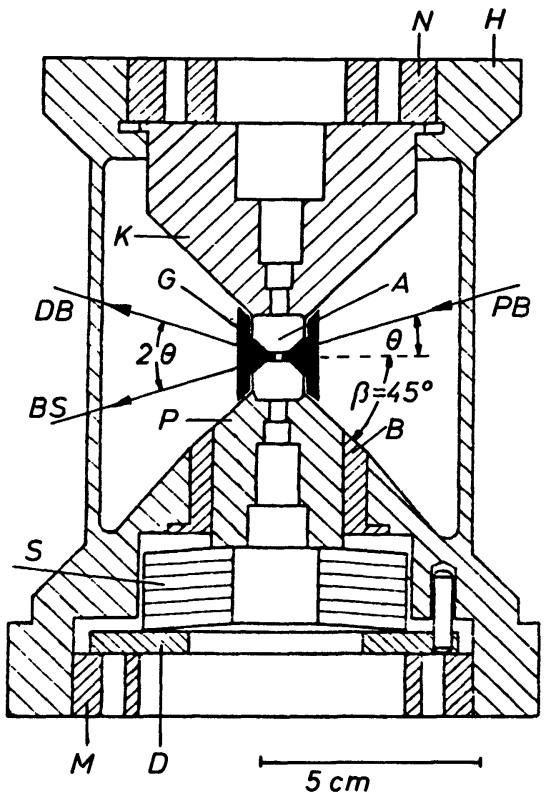

Fig. 2. - High pressure cell for neutron experiments. PB, primary neutron beam; DB, diffracted beam; BS, to beam stop; A, anvil ; B, bushing; D, distortion protector; G, gasket ; $H$, housing; $K$, upper anvil seat, can be removed for sample loading work; $M, N$, nuts ; $P$, piston ; $S$, buffersprings.

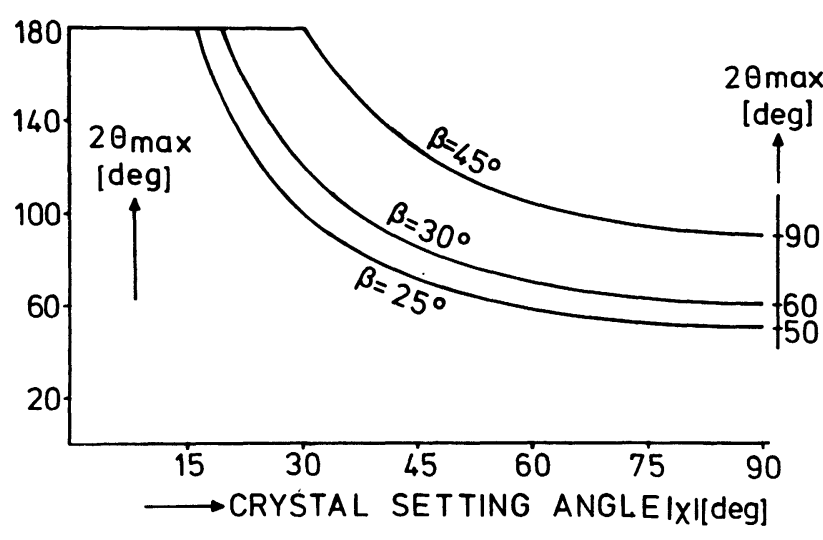

Fig. 3. - Maximum $2 \theta$ possible for measurements in the bisecting angle setting depending on the diffractometer setting angle $\chi$ for different thickness $\beta$ of the belt shaped diffracting window.

the $10 \mathrm{kbar}$ experiment [11]. We suppose that ingenious changings in shape and material of gasket and anvils could improve the sample volume. the ratio of peak to background or the pressure available. 


\section{References}

[1] Weir, C. E., Block, S. and Piermarini, G. J., J. Res. Nat. Bur. Stand. 69C (1975) 275.

[2] Fourme, R., J. Appl. Crystallogr. 1 (1978) 23.

[3] Weir, C. E., Piermarini, G. J. and Block, S., Rev. Sci. Instrum. 40 (1969) 1133.

[4] Merill, L. and Basset, W. A., Rev. Sci. Instrum. 45 (1976) 230.

[5] Keller, R. and Holzapfel, W. B., Rev. Sci. Instrum. 48 (1977) 517.

[6] Schifferl, D., Jamieson, J. C. and Lenko, J. E., Rev. Sci. Instrum. 49 (1978) 359.
[7] Ahsbahs, H., Rev. Sci. Instrum. 55 (1984) 99.

[8] Sidhu, S. S., Heaton, L., Zauberis, D. D. and CamPOS, F. P., J. Appl. Phys. 27 (1956) 1040.

[9] Hellner, E. and Ahsbahs, H., Annex Annual Report I.L.L., Grenoble (1981) 113.

[10] Ahsbahs. H.. Sowa. H. und Hellner. E.. Fortschr. Miner. 60 Beih. 1 (1982) 35.

[11] SowA, H., Dissertation Marburg (1983). 